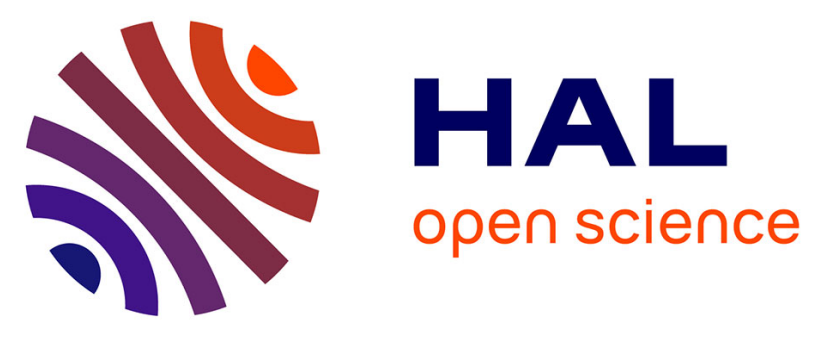

\title{
Natural Chlordecone Degradation Revealed by Numerous Transformation Products Characterized in Key French West Indies Environmental Compartments
}

Marion L. Chevallier, Oriane Della-Negra, Sébastien Chaussonnerie, Agnès Barbance, Delphine Muselet, Florian Lagarde, Ekaterina Darii, Edgardo Ugarte, Ewen Lescop, Nuria Fonknechten, et al.

\section{To cite this version:}

Marion L. Chevallier, Oriane Della-Negra, Sébastien Chaussonnerie, Agnès Barbance, Delphine Muselet, et al.. Natural Chlordecone Degradation Revealed by Numerous Transformation Products Characterized in Key French West Indies Environmental Compartments. Environmental Science and Technology, 2019, 53 (11), pp.6133-6143. 10.1021/acs.est.8b06305 . hal-02309073

\section{HAL Id: hal-02309073 \\ https://hal.science/hal-02309073}

Submitted on 3 Apr 2020

HAL is a multi-disciplinary open access archive for the deposit and dissemination of scientific research documents, whether they are published or not. The documents may come from teaching and research institutions in France or abroad, or from public or private research centers.
L'archive ouverte pluridisciplinaire HAL, est destinée au dépôt et à la diffusion de documents scientifiques de niveau recherche, publiés ou non, émanant des établissements d'enseignement et de recherche français ou étrangers, des laboratoires publics ou privés. 
This document is confidential and is proprietary to the American Chemical Society and its authors. Do not copy or disclose without written permission. If you have received this item in error, notify the sender and delete all copies.

\section{Natural chlordecone degradation revealed by numerous transformation products characterized in key French West Indies environmental compartments}

\begin{tabular}{|c|c|}
\hline Journal: & Environmental Science \& Technology \\
\hline Manuscript ID & es-2018-06305s \\
\hline Manuscript Type: & Article \\
\hline $\begin{array}{r}\text { Date Submitted by the } \\
\text { Author: }\end{array}$ & 09-Nov-2018 \\
\hline Complete List of Authors: & 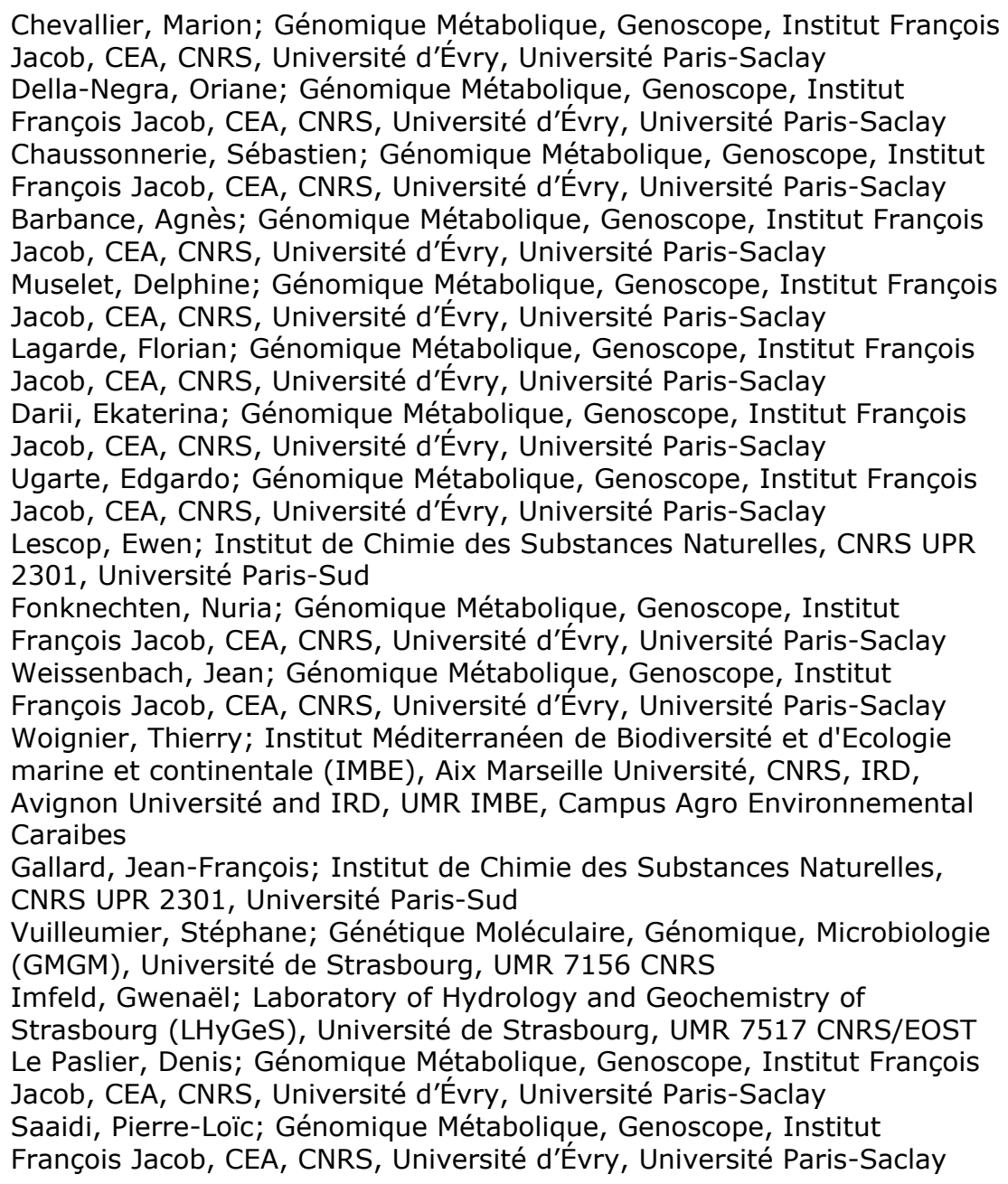 \\
\hline
\end{tabular}




\section{SCHOLARONE ${ }^{m}$ Manuscripts}




\section{Natural chlordecone degradation revealed by}

2 numerous transformation products characterized in

3 key French West Indies environmental

4 compartments

5 Marion L. Chevallier ${ }^{a, 1}$, Oriane Della-Negra ${ }^{a, 1}$, Sébastien Chaussonnerie $e^{a, 2}$, Agnès Barbance ${ }^{a, 2}$,

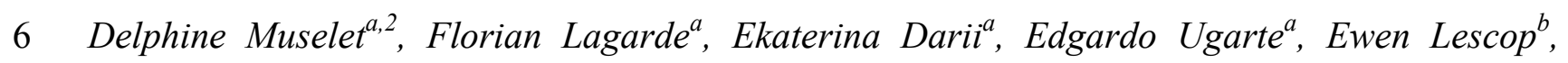

$7 \quad$ Nuria Fonknechten ${ }^{a}$, Jean Weissenbach ${ }^{a}$, Thierry Woignier ${ }^{c}$, Jean-François Gallard ${ }^{b}$, Stéphane

8 Vuilleumier $^{d}$, Gwenaël Imfeld ${ }^{e}$, Denis Le Paslier ${ }^{a, 3}$, Pierre-Loïc Saaidi ${ }^{a, 3}$.

10 aánomique Métabolique, Genoscope, Institut François Jacob, CEA, CNRS, Université d'Évry,

11 Université Paris-Saclay, Evry, France.

12 ' Institut de Chimie des Substances Naturelles. CNRS - UPR 2301 Bâtiment 27, 1 avenue de la

13 Terrasse 91198 Gif-sur-Yvette Cedex, France.

$14{ }^{\mathrm{c}}$ Institut Méditerranéen de Biodiversité et d'Ecologie marine et continentale (IMBE), Aix

15 Marseille Université, CNRS, IRD, Avignon Université and IRD, UMR IMBE, Campus Agro

16 Environnemental Caraïbes B. P. 214 Petit Morne, 97235, Le Lamentin, Martinique, France. 
$17{ }^{\mathrm{d}}$ Génétique Moléculaire, Génomique, Microbiologie (GMGM), Université de Strasbourg, UMR 187156 CNRS, 28 rue Goethe, 67000 Strasbourg Cedex, France.

19 e Laboratory of Hydrology and Geochemistry of Strasbourg (LHyGeS), Université de Strasbourg,

20 UMR 7517 CNRS/EOST, 1 Rue Blessig, 67084 Strasbourg Cedex, France.

$21 \quad{ }^{1}$ M.C. and O.D.N. contributed equally

$22 \quad{ }^{2}$ S.C., A.B. and D.M. also contributed equally

$23{ }^{3}$ To whom correspondence may be addressed: Pierre-Loïc Saaidi, or Denis Le Paslier, E-Mail:

24 plsaaidi@genoscope.cns.fr or denis@genoscope.cns.fr.

25

26 
28 A large part of the well-established Persistent Organic Pollutants is composed of organochlorine

29 pesticides that are still poisoning our environment. Among them, the insecticide chlordecone

30 shares with mirex a particularly recalcitrant perchlorinated bishomocubane structure. Its

31 production and application has caused long-term environmental pollutions in the James River

32 area (US) and in the French West Indies (FWI) that resulted in acute human health issues and

33 social crisis. Chlordecone is considered virtually non-biodegradable in the environment mainly

34 due to absence of transformation products (TP) and high levels of chlordecone concentration

35 even after decades of prohibition. Here, 19 TP were identified by untargeted GC-MS and LC-

36 HRMS analyses of a series of anoxic degradation experiments, and classified into five distinct

37 families. Chemical synthesis and NMR spectroscopy allowed structural elucidation of 19 so far

38 unidentified TP. Among the 19 TP detected in key FWI compartments (soils, river, mangrove

39 and sediments), 2,4,5,6,7-pentachloroindene showed similar concentration levels as chlordecone.

40 Microcosm experiments on three FWI soils confirmed intrinsic potential for chlordecone natural

41 degradation. These results not only challenge the paradigm of chlordecone persistence over

42 periods of centuries, but also raise the overlooked issue of extensive pollution of soil and aquatic 43 ecosystems by chlordecone TP worldwide.

44

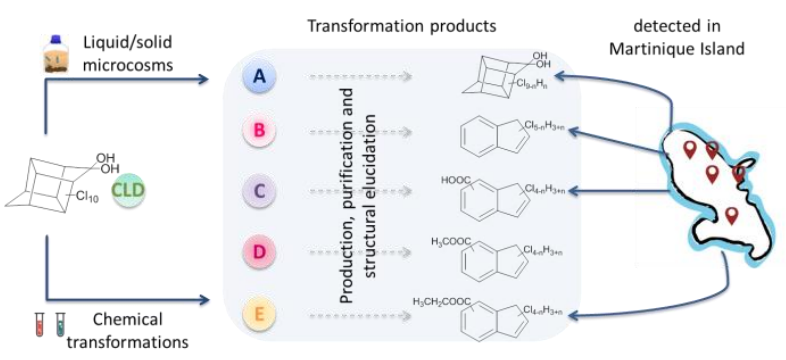


47 KEYWORDS. Chlordecone | persistant organic pollutant | pollution | biodegradation |

48 structure elucidation | transformation product

49

50 
INTRODUCTION

52 The organochlorine (OC) insecticides have been applied extensively for pest control in

53 agriculture worldwide for decades. Their use has gradually been prohibited since the 1970s

54 because of their biological biomagnification, high toxicity and long persistence in the

55 environment. Many OC synthesized from hexachlorocyclopentadiene[1] belong to the

56 Stockholm convention list of Persistent Organic Pollutants (POPs), ie aldrin, dieldrin, endrin,

57 chlordan, heptachlor, mirex, chlordecone and endosulfans. Among them, the insecticides

58 chlordecone and mirex, that has been commonly used as fire-retardant, represent a particular

59 class of OC as they both arise from hexachlorocyclopentadiene dimerization $[1,2]$ and share a

60 number of characteristics such as low value of molecular orbital energy, high hydrophobicity and

61 low $\mathrm{K}_{\text {ow }}[3]$. Chlordecone is also known as a TP of mirex[4] and kelevan, another insecticide

62 mainly used in Europe[5]. The resulting highly stable perchlorinated bishomocubane structure

63 renders such OC extremely recalcitrant to environmental conditions. While chlordecone

64 formulations produced in the US (as Kepone) and Brazil (as Curlone) have been mainly used in

65 the Caribbean area, in Central America and Africa[6], mirex utilization has been reported in

66 North America[7, 8], Latin America, Europe[6] and more recently in China[9]. Finally, by its

67 direct use or its in situ formation, chlordecone is virtually present all over the world and has been

68 even detected in the coral reefs of the French Polynesia[10], we thus chose it as a pertinent and

69 challenging pollutant from the hexachlorocyclopentadiene-based OC.

70 To date, chlordecone has already led to two environmental disasters: (1) contamination of the

71 environment nearby the Hopewell chlordecone production plant (U.S.) in 1975 causing massive

72 pollution of the James River over 100 miles for decades and acute exposition of workers[11]. On

73 a wider scale, extensive use of chlordecone from 1972 to 1993 in banana plantations of the 
74 French West Indies (FWI) has resulted in a long-term pollution of environmental compartments

75 and the local food chain (soils, water resources, farmed animals, fish)[6, 12, 13]. Chronic

76 exposure to chlordecone has resulted in human health problems [13-26] and subsequent socio-

77 economic issues for the FWI and the James River area [27-30].

78 Following application, chlordecone sorbs onto soil and sediments particles, especially organic

79 rich FWI matrices. The commonly admitted paradigm of absolute chlordecone persistence for

80 decades/centuries in the FWI based on a leaching model[31] has been recently confirmed by two

81 studies suggesting only marginal degradation in tropical soils, if any [32, 33]. Generally, POPs

82 pollution is assessed and followed by environmental monitoring of the parent molecule, with

83 restricted efforts dedicated to the possible TP in situ formed and their consequences as

84 exemplified for aldrin. In the case of chlordecone, several bacterial degradation experiments

85 suggested two main TP families evidenced by GC-MS [34, 35] [36, 37]. Despite extensive

86 analytical studies on chlordecone contamination in the FWI[6], the only chlordecone derivatives

87 hitherto detected in environmental samples, i.e. chlordecol and 8-monohydrochlordecone, turn to

88 be contaminants from former commercial formulations. However, as only targeted analyses were

89 applied, presence of other TP cannot be excluded.

90 In this context, we intended (i) to clear the exact structure of the previously reported chlordecone

91 TP and (ii) to extend our knowledge on the structural diversity of chlordecone TP possibly

92 formed in laboratory and in the field in order to question the paradigm of chlordecone

93 environmental non-biodegradability. To address these issues, we applied a dual GC-MS- and

94 LC-HRMS-based approach on both microbiological and chemical degradation processes and also

95 on FWI soil, water and sediments samples. 

MATERIAL AND METHODS

\section{Chemicals and Analytics}

99 All used chemicals, analytical and purification methods are described in detail in Supporting

100 Information (SI) (Supporting Methods).

\section{Extraction of natural samples}

\section{$102 \quad$ Field sites and soil sampling}

103 Each sample was collected in Martinique Island. Soils (andosol, nitisol, ferralsol) coming from

104 the vicinity of the "Montagne Pelée" volcano and bed sediments were sampled from the 0-30 cm 105 layer and conserved in glass box; whereas river and mangrove water were collected from the 0$10630 \mathrm{~cm}$ above the surface with glass bottles (Table S4).

\section{Procedure for sample chemical extraction}

108 Each sample was extracted in duplicate. For soils and sediments: to $4 \mathrm{~g}$ of crude sample, $15 \mathrm{~mL}$ 109 of milli Q water was added, followed by acidification to $\mathrm{pH} 1$ with $\mathrm{HCl}(1 \mathrm{M})$ and vortex. After 110 decantation the supernatant was extracted with DCM (12 x $15 \mathrm{~mL})$ and the pellet was washed

111 twice with DCM (15 mL). For river and mangrove water: $0.75 \mathrm{~L}$ of water sample was acidified to $112 \mathrm{pH} 1$ with $\mathrm{HCl}(1 \mathrm{M})$ and extracted with DCM $(12 \times 350 \mathrm{~mL})$. In each case, organic layers were 113 pooled, concentrated in vacuo and analyzed in duplicated injection using GC-MS (in 114 hexane/acetone 85:15) and LC-MS (in $10 \mathrm{mM} \mathrm{NH}_{4} \mathrm{OAc}$ buffer/MeCN 4:1) protocols.

\section{Production and purification of chlordecone main TP}

116 TP productions were monitored by GC-MS and LC-MS. 


\section{TP A1}

118 To a solution of chlordecone $\left(100 \mathrm{mg}, 2.010^{-4} \mathrm{~mol}, 1 \mathrm{eq}\right)$ in degassed water $(300 \mathrm{~mL})$ were 119 added sodium sulfide $\left(2.2 \mathrm{~g}, 2.810^{-2} \mathrm{~mol}, 140\right.$ eq.) and vitamin $\mathrm{B}_{12}\left(40 \mathrm{mg}, 2.910^{-5} \mathrm{~mol}, 0.15\right.$

120 eq.). The reaction was carried out under $\mathrm{N}_{2}$ atmosphere at room temperature (rt) for 30 h. It was 121 then quenched with $\mathrm{HCl}(6 \mathrm{M})$ to $\mathrm{pH} 4.0$ and degassed with $\mathrm{N}_{2}$ for one hour to evacuate 122 hydrogen sulfide. The aqueous reaction mixture was extracted with DCM (3 x $200 \mathrm{~mL})$ and the 123 combined organic phases were concentrated in vacuo to give a brown crude oil. A first 124 purification step was performed using a Combi Flash ${ }^{\circledR}$ Companion $\AA$ Elution at a flowrate of 40 $125 \mathrm{~mL} / \mathrm{min}$ using heptane as solvent $\mathrm{A}$ and a mixture of $\mathrm{DCM} /\left(\mathrm{CH}_{3}\right)_{2} \mathrm{CO}(1: 1 ; \mathrm{V} / \mathrm{V})$ as solvent $\mathrm{B}$.

126 Elution started at $0 \% \mathrm{~B}$ for $7 \mathrm{~min}$, followed by a linear gradient reaching $50 \% \mathrm{~B}$ within 5 min, a 127 second linear gradient reaching $100 \%$ B within 3 min and remained 15 min at 100\% B. Fractions 128 containing A1 (from 8 to $29 \mathrm{~min}$ ) were pooled and concentrated under reduced pressure. A 129 second purification step was performed using a preparative HPLC system. Isocratic elution made 130 of tetrahydrofuran/MeCN/( $\left.\mathrm{NH}_{4}\right)_{2} \mathrm{CO}_{3}$ buffer (10 mM, pH 9.5) (29:29:42; V/V/V) was applied at 131 a flowrate of $20 \mathrm{~mL} / \mathrm{min}$. Fractions containing A1 (retention time of $9 \mathrm{~min}$ ) were pooled, 132 acidified to $\mathrm{pH} 3$ with $\mathrm{HCl}(6 \mathrm{M})$, extracted 3 times with DCM, and concentrated under reduced 133 pressure, to give the title compound A1 (46.4 mg; $9.810^{-5} \mathrm{~mol} ; 50 \%$ ) as a white solid. All NMR, 134 GC-MS and LC-HRMS analyses for A1 are available in Figures S16, S23, S27-S28.

\section{TP B1, B2 and B3/B4}

136 To a solution of chlordecone (200 mg, $3.910^{-4}$ mol, 1 eq.) and vitamin $B_{12}\left(60 \mathrm{mg}, 5.810^{-5}\right.$ mol, 1370.15 eq.) in degassed $\mathrm{H}_{2} \mathrm{O} / \mathrm{MeOH}$ 64:36 (250 mL), was added titanium(III) citrate (50 mL, 3.3 $13810^{-3}$ mol, 8.4 eq.) basified to $\mathrm{pH} 12.7$ with $\mathrm{NaOH}(3 \mathrm{M})$. Reaction mixture was stirred under $\mathrm{N}_{2}$ 
139 atmosphere at room temperature for $80 \mathrm{~min}$ and, quenched by contact with $\mathrm{O}_{2}$. Extraction with 140 pentane $(5 \times 250 \mathrm{~mL})$ followed by concentration under reduced pressure gave rise to a white 141 crude solid.B1, B2 and B3/B4 were purified using a preparative HPLC system. Isocratic elution $142\left(\mathrm{MeCN} / \mathrm{H}_{2} \mathrm{O} \quad 7: 3 ; \mathrm{v} / \mathrm{v}\right)$ was applied at a flowrate of $25 \mathrm{~mL} / \mathrm{min}$. Fractions containing B1 143 (retention time of $42 \mathrm{~min}$ ), B2 (retention time of $28 \mathrm{~min}$ ) and B3/B4 (retention time of $32 \mathrm{~min}$ ) 144 were pooled separately, extracted 3 times with pentane and concentrated under reduced 145 pressure.Each compound was then purified through PLC (Preparative Layer Chromatography; 146 Merck, PLC Silica gel, $1 \mathrm{~mm}, \mathrm{~F}_{254}, 20$ x 20) (cyclohexane/EtOAc 9:1); B1, B2 and B3/B4 147 retardation factors were respectively $0.78,0.68$ and $0.88 . \mathrm{B} 1\left(32.6 \mathrm{mg} ; 1.210^{-4} \mathrm{~mol} ; 30 \%\right)$, B2 $148 \quad\left(3.0 \mathrm{mg} ; 1.210^{-5} \mathrm{~mol} ; 3 \%\right)$ and B3/B4 (4.1 mg; $\left.1.310^{-5} \mathrm{~mol} ; 4 \%\right)$ were finally obtained as white 149 solids. All NMR, GC-MS and LC-HRMS analyses for B1, B2, B3-B4 are available in Figures $150 \mathrm{~S} 17-\mathrm{S} 18, \mathrm{~S} 23, \mathrm{~S} 29-\mathrm{S} 45 .{ }^{13} \mathrm{C}$-enriched B1 synthesis and purification protocols are described in SI 151 (Supporting Methods).

152 TP C1, C2, C3 and C4

153 To a solution of chlordecone (100 mg, $2.010^{-4} \mathrm{~mol}, 1$ eq.) and vitamin $\mathrm{B}_{12}\left(40 \mathrm{mg}, 2.910^{-5} \mathrm{~mol}\right.$, 1540.3 eq.) in degassed water/acetone 3:1 (300 mL), was added zero-valent iron $\left(2 \mathrm{~g}, 3.610^{-2} \mathrm{~mol}\right.$, 155182 eq.). The reaction mixture was carried out in a glovebox $\left(\mathrm{N}_{2} / \mathrm{H}_{2}, 98: 2, \mathrm{~V} / \mathrm{V}\right)$ at room 156 temperature for 2 months. After quenching by contact with $\mathrm{O}_{2}$, acetone was evaporated under 157 reduced pressure, the resulting aqueous phase was acidified to $\mathrm{pH} 1(\mathrm{HCl} 6 \mathrm{M})$ and extracted 158 with DCM $(10 \times 100 \mathrm{~mL})$. The combined organic layers were finally concentrated under reduced 159 pressure.A first purification step was carried out using preparative HPLC. Elution was performed 160 at a flowrate of $25 \mathrm{~mL} / \mathrm{min}$ using $\mathrm{NH}_{4} \mathrm{OAc}$ buffer $\left(10 \mathrm{mM}\right.$; pH 7 adjusted with $\left.\mathrm{NH}_{4} \mathrm{OH}\right)$ as 161 solvent $\mathrm{A}$ and $\mathrm{MeCN}$ as solvent $\mathrm{B}$. Elution started at 12\% B for $4 \mathrm{~min}$, followed by a linear 
162 gradient reaching 29\% B within $11 \mathrm{~min}$, followed by a second linear gradient reaching 50\% B

163 within $15 \mathrm{~min}$ and a third one reaching 100\% B within 6 min. Fractions containing respectively

164 C1-C2 and C3-C4 (from 21.5 to 23 and 25 to 28 min respectively) were pooled and MeCN was

165 removed under reduced pressure. The resulting aqueous layers were basified to $\mathrm{pH} 10$ with

$166 \mathrm{~K}_{2} \mathrm{CO}_{3}(10 \mathrm{mM}, \mathrm{pH} 10)$, washed with $50 \mathrm{ml}$ of hexane/EtOAc 95:5 (V/V), acidified to $\mathrm{pH} 3$ with

$167 \mathrm{HCl}(12 \mathrm{M})$ and extracted three times with hexane/EtOAc 95:5 (V/V). The combined final

168 organic layers were concentrated under reduced pressure to give the title compounds C1-C2 (3.0

$\left.169 \mathrm{mg} ; 1.010^{-5} \mathrm{~mol} ; 5 \%\right)$ and $\mathrm{C} 3-\mathrm{C} 4\left(1.5 \mathrm{mg} ; 5.710^{-6} \mathrm{~mol} ; 3 \%\right)$ as white solids. All NMR and LC-

170 HRMS analyses for C1-C2 and C3-C4 are available in Figures S24-S25, S46-S56.

171 Production, and purification protocols of transformation products D1, D2, D3 and D4 are

172 described in SI (Supporting Methods). All NMR and LC-HRMS are available in Figures S19-

173 S20, S23, S57-S66.

174

175 Anoxic microbiological experiments

176 Liquid/solid microcosm experiments and analytical protocols are described in SI (Supporting 177 Methods).

\section{Diversity of chlordecone TP from anoxic biodegradation}

181 Both early[34, 35] and recent [36, 37] studies of bacterial chlordecone degradation suggested two 182 main TP families: hydrochlordecones from reductive dechlorination reactions (family A), and 
183 polychloroindenes formed after ring-opening and elimination steps (family B) (Figure 1).

184 Another study with the Archaeon Methanosarcina thermophila suggested quantitative

185 chlordecone conversion into unknown polar and nonpolar metabolites based on silica gel thin-

186 layer chromatography (TLC)[38]. The technique used for hydrochlordecones and

187 polychloroindenes TP produced by consortium 86[36] was applied here to confirm the

188 uniqueness of TP formed during bacterial and archaeal chlordecone degradation. Retardation

189 factor (Rf) values for polychloroindenes corresponded to those of nonpolar TP in

190 Methanosarcina thermophila cultures[38], while hydrochlordecones behaved like chlordecone

191 (Figure S1). Hence, hydrochlordecones cannot represent the previously reported unknown

192 archaeal polar TP and define a novel, so far undescribed, family of chlordecone TP.

193 Further novel chlordecone TP during incubation of chlordecone in presence of consortium 86

194 and Citrobacter sp. 86 were searched for using measurement of chloride concentration, GC-MS,

195 GC-FID, and LC-MS-Orbitrap. After 250 days of incubation, chloride concentrations increased

196 by $18.8 \pm 0.9 \mathrm{mg} / \mathrm{L}$ (i.e., $5.5 \pm 0.3 \mathrm{Cl}$ atoms per chlordecone molecule) in consortium 86

197 cultures, and by $19.7 \pm 1.7 \mathrm{mg} / \mathrm{L}$ (i.e., $5.8 \pm 0.5 \mathrm{Cl}$ atoms per chlordecone molecule) in

198 Citrobacter sp. 86 cultures, corresponding to complete chlordecone transformation (Figure 1

199 and Figure S13). Chloride recovery indicated the occurrence of other, so far undetected highly

200 dechlorinated $\mathrm{TP}$, in addition to previously reported main TP $\mathrm{B}_{1}\left(\mathrm{C}_{9} \mathrm{Cl}_{5} \mathrm{H}_{3}\right)$ and $\mathrm{A}_{1}$

$201 \quad\left(\mathrm{C}_{10} \mathrm{Cl}_{9} \mathrm{H}_{3} \mathrm{O}_{2}\right)[36]$.

202 While GC-FID analysis confirmed that volatile metabolites A1 and B1 occurred in all microbial 203 experiments (Figure S14), four new polar chlorinated TP $(\mathrm{Ci}, \mathrm{i}=1,2,3,4)$ of generic formula

$204 \mathrm{C}_{10} \mathrm{Cl}_{4-\mathrm{n}} \mathrm{O}_{2} \mathrm{H}_{4+\mathrm{n}}(\mathrm{n}=0,1)$ were also identified in all chlordecone-degrading microcosms using LC-

205 ESI-MS-Orbitrap in negative mode (Figure 1 and Figures S24-S25). TLC analysis initially 
206 indicated a high match with unknown polar TP[38]. Tandem mass spectrometry using collision 207 induced dissociation (CID) (LC-MS ${ }^{2}$ and $\mathrm{LC}-\mathrm{MS}^{3}$ ) then showed that the four TP followed

208 similar fragmentation patterns with characteristic $\mathrm{CO}_{2}$ loss. The UV-visible absorption profiles of 209 all $\mathrm{TP} \mathrm{Ci}(\mathrm{i}=1,2,3,4)$ were close to those reported and tentatively assigned to 210 pentachloroindenes[39] (Figure S2).

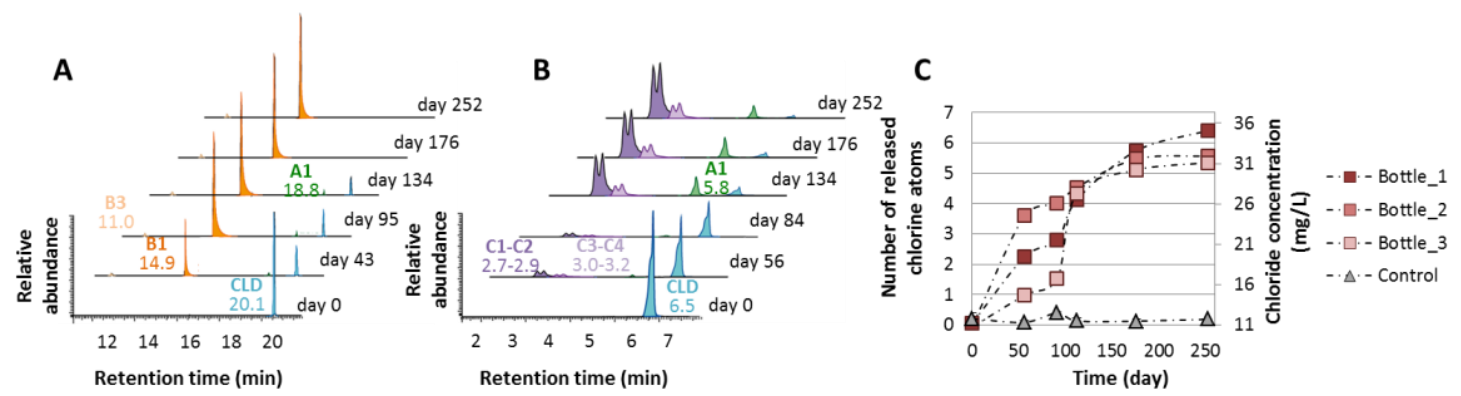

212 Figure 1. TP production during chlordecone degradation by Citrobacter sp. 86 (A) GC-MS full 213 scan analysis during chlordecone degradation by Citrobacter sp. 86 and detection of CLD (blue), 214 A1 (green), B1 (orange) and B3 (yellow) TP. (B) TP production during chlordecone degradation 215 by Citrobacter sp. 86 using LC-MS-Orbitrap analysis and detection of CLD (blue), A1 (green), 216 C1 (purple), C2 (purple), C3 (magenta) and C4 (magenta) TP Extract ion chromatograms for 217 quasimolecular ion $[\mathrm{M}-\mathrm{H}]^{-}$of $\mathrm{m} / \mathrm{z}=506.6797 ; 472.7187 ; 296.8852 ; 260.9271$ (C) Chloride 218 concentration and average number of released chlorine atoms per consumed chlordecone 219 molecule during chlordecone degradation by Citrobacter sp. 86.

221 In parallel, laboratory microcosms with contaminated FWI soils (typically from 0.1 to $30 \mathrm{mg}$ 222 chlordecone/kg of dry soil) were incubated for three years under $\mathrm{N}_{2} / \mathrm{H}_{2}$ atmosphere at room 223 temperature and in the dark to evaluate the capacity of native FWI soil microbiotes to degrade 224 residual chlordecone (Figure S3). For each condition (soil/liquid medium), several replicates 225 were collected over time using a sacrificial approach to evaluate produced chlordecone TP. All 226 analyzed samples contained several chlordecone TP among which 10 new derivatives. 
227 Chlordecol, a known chlordecone contaminant in former commercial formulations that is present 228 in FWI soils at low level[40], was also systematically found.

229 The GC-FID technique turned out to be inappropriate due to high background from soil samples 230 and low chlordecone concentration. Successive liquid-liquid extractions were thus combined to 231 concentrate chlordecone TP prior to GC-MS and LC-ESI-MS-Orbitrap analyses (Tables S2-S3).

232 Newly identified chlordecone TP were classified into two families (named D and E), with 233 respective generic formula $\mathrm{C}_{11} \mathrm{Cl}_{4-\mathrm{n}} \mathrm{O}_{2} \mathrm{H}_{6+\mathrm{n}}(\mathrm{n}=0,1)$ and $\mathrm{C}_{12} \mathrm{Cl}_{4-\mathrm{n}} \mathrm{O}_{2} \mathrm{H}_{8+\mathrm{n}}(\mathrm{n}=0,1)$. MS spectra 234 from GC-MS analysis revealed the likely occurrence of methyl and ethyl ester moieties for 235 families D and E, respectively. A series of fragments $\left(\mathrm{C}_{9} \mathrm{Cl}_{\mathrm{x}} \mathrm{H}_{\mathrm{y}}{ }^{+}, \mathrm{x}=5,4,3,2 ; \mathrm{y}=4,3,2\right)$ were 236 common to compounds Bi $(i=1,2,3), \mathrm{Dj}(\mathrm{j}=1,2,3,4)$ and $\mathrm{Ek}(\mathrm{k}=1,2,3,4)$, suggesting a 237 shared aromatic polychloroindene core ring system, with methyl- and ethyl-polychloroindene238 carboxylate structures for D and E families, respectively (Figure 2 and Figures S19-S22). 239 Altogether, 19 chlordecone TP were discovered from liquid and solid microcosm experiments 240 using the untargeted analytical approach (Figure S15).

\section{Production and purification of chlordecone TP}

243 The major chlordecone TP detected in biodegradation experiments (Figure 2) were synthesized 244 and purified on a (sub)milligram scale to achieve complete structural elucidation using NMR 245 spectroscopy. Chlordecone degradation by bacterial consortia and Citrobacter sp. 86 takes 246 several weeks to several months[36] and only allowed partial TP elucidation (A1, B1 and Ci $247(\mathrm{i}=1,2,3,4))$. We reasoned that different chemical degradation conditions may favor sufficient 248 production of each type of TP for subsequent purification. For example, photochemical 
249 degradation led to mono- and di-hydrochlordecone derivatives, each with about 1\% yield[41].

250 All other conditions under which chlordecone degradation was reported required a reducing

251 agent, either alone[42] or in combination with vitamin $\mathrm{B}_{12}[37-39,43-45]$.

252 Thus, monitoring of chlordecone degradation by GC-MS and LC-MS was used here to determine 253 suitable conditions for selective formation of metabolites from each TP family, including the 254 three novel TP families identified here for the first time. Addition of reducing agents and metal 255 complexes previously applied to enhance mirex degradation[46] were tested (Table S1). 256 Application of degradation conditions (acetoin, vitamin $\mathrm{B}_{12}$ and methanol) previously shown to 257 selectively lead to the formation of polychloroindenes[39] also resulted in C and D families of 258 TP. Similarly, two other protocols (vitamin $\mathrm{B}_{12}$, ethanol and either zero-valent zinc or 1,4259 dithiothreitol) reported to result in a tentatively assigned pentachloroindene as a unique 260 chlordecone TP[43] also yielded lower chlorinated indenes, as well as several TP of the C and E 261 families (Figure S7).

262 Eventually, we selected 5 protocols of TP production among the 21 tested degradation conditions

263 (Table S1, Figure 2). For instance, titanium citrate and zero-valent iron without vitamin $\mathrm{B}_{12}$ 264 selectively resulted in selective formation of hydrochlordecones. Most importantly, the 265 combination of sodium sulfide and vitamin $B_{12}$ specifically led to the production of 266 monohydrochlordecone A1 (in up to 50\% yield after purification). Polychloroindenes and 267 polychloroindene carboxylic acids were formed at highest levels upon amendment with vitamin $268 \mathrm{~B}_{12}$ (Figure 2 and Table S1). Worthy of note, tested reducing agents did not specifically favor TP 269 from one of these two families, but systematically produced a mixture of B and C TP. Zero270 valent iron may slightly enhance production of $\mathrm{C}$ family $\mathrm{TP}$, whereas $\mathrm{TP}$ of the $\mathrm{B}$ family 271 prevailed in assays with titanium citrate. On a preparative scale, addition of methanol 
272 significantly improved the reproducibility of B family TP production. From the same 273 experimental batch, B1, B2 and B3 TP were isolated with yields up to $30 \%, 3 \%$ and $4 \%$, 274 respectively. Compounds $\mathrm{C} 1-\mathrm{C} 2$ (5\% yield) and $\mathrm{C} 3-\mathrm{C} 4$ (3\% yield) were obtained as non275 separable pairs of isomers. Indeed, when a single $\mathrm{Ci}(\mathrm{i}=1,2,3,4) \mathrm{TP}$ was isolated using 276 preparative HPLC, partial interconversion to its isomer was observed after evaporation, 277 demonstrating the existence of an equilibrium between pairs of isomers. Finally, 278 supplementation of reaction mixtures leading to B and C TP with either methanol or ethanol led 279 to production of either D or E TP. Purification of pairs D1-D2 and D3-D4 was achieved in 5\% 280 and 3\% yield, respectively. 
A

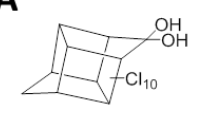

Chlordecone (CLD)

B

Transformation conditions:

Citrobacter sp. $86^{i}$

Soil-Microcosms

Sodium sulfide

Zero valent iron ${ }^{\mathrm{ii}}$

Titanium (III) citrate

Sodium sulfide + vitamin $B_{12}$

Zero valent iron + vitamin $\mathrm{B}_{12}$

Titanium (III) citrate + vitamin $\mathrm{B}_{12}$ $\left(\mathrm{H}_{2} \mathrm{O}\right)^{\mathrm{iii}}$

Titanium (III) citrate + vitamin $\mathrm{B}_{12}$ $\left(\mathrm{H}_{2} \mathrm{O} / \mathrm{MeOH}\right)$

Titanium (III) citrate + vitamin $\mathrm{B}_{12}$ $\left(\mathrm{H}_{2} \mathrm{O} / \mathrm{EtOH}\right)$
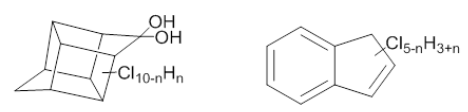

ydrochlordecones

(n=1, 2, 3)

$$
(n=0,1)
$$

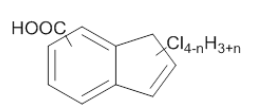

B) Polychloroindene caboxylic acids (C) $(\mathrm{n}=0,1)$

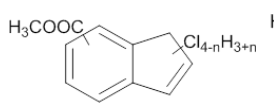

Methylpolychloroindene carboxylates (D) $(n=0,1)$

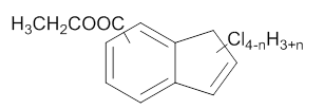

Ethylpolychloroindene carboxylates (E) $(n=0,1)$
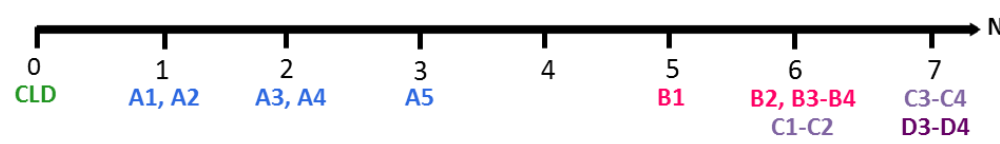

Number of released chlorine atoms

Detected compounds:

Chlordecone

$\bigcirc$ ATP $B$ TP

$\bigoplus D T P$

$\bigoplus E T P$

D1-D2 E3-E4.
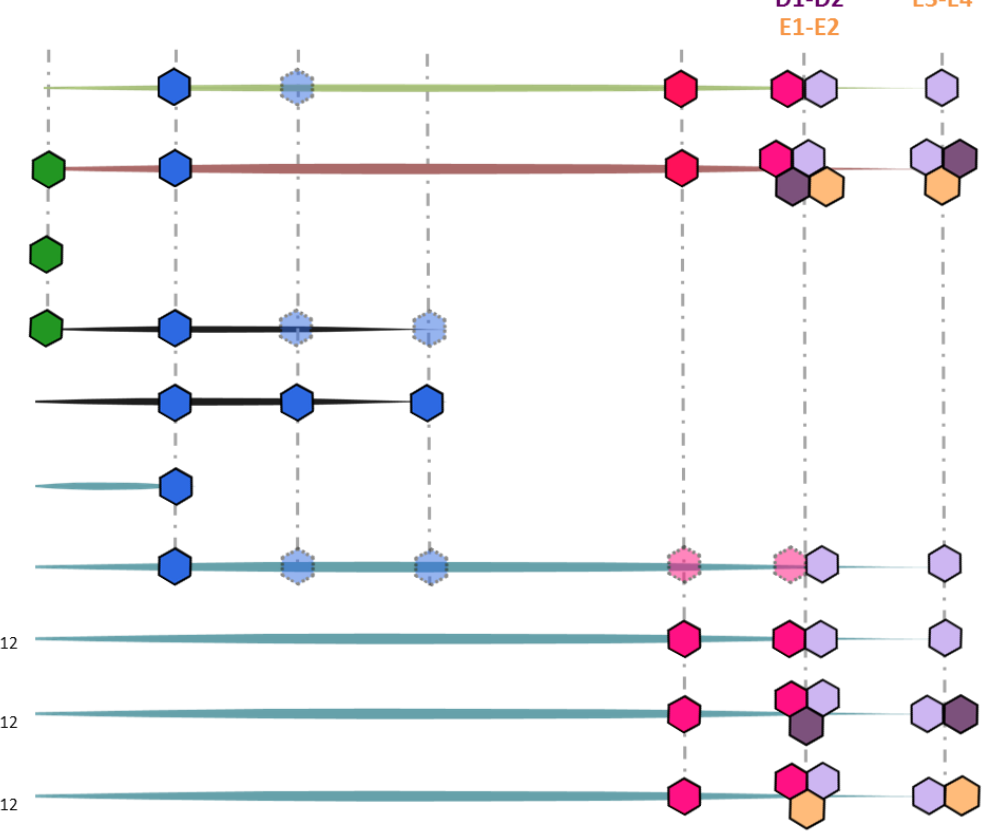

283 Figure 2. Chlordecone TP (A) Five families of observed chlordecone TP (B) Chemical 284 conditions for chlordecone degradation and released of one to seven chloride atoms. 8285 monohydrochlordecone was assigned to A2. A3 and A4 correspond to dihydrochlordecones, and 286 A5 to a trihydrochlordecone. 
A1, the major hydrochlordecone observed in recent work[36] previously identified as either 9- or

290 10-monohydrochlordecone[42] and also formed after In Situ Chemical Reduction Daramend®

291 treatment of an FWI field[47], was identified here as 10-monohydrochlordecone. Indeed,

292 replacement of a chlorine atom by a hydrogen in chlordecone can only lead to four different

293 regioisomers, i.e. 6-, 8-, 9- or 10-monohydrochlordecones (Figure S5). The obtained ${ }^{13} \mathrm{C}$ NMR

294 spectrum for this TP showed six signals, indicating the presence of a conserved vertical plane of

295 symmetry in A1. To satisfy this feature, the hydrogen atom can only be positioned on carbon 10.

296 TP belonging to TP families B, C, D and E likely possess an indene core structure as assigned

297 previously to TP B1 following chemical conversion to commercially available indane[37]. The

298 same hydrogenation protocol for TP pairs C1-C2 and C3-C4 unambiguously resulted in the

299 formation of indane-4-carboxylic acid confirming that TP family $\mathrm{C}$ features a carboxyindene

300 aromatic ring system (Figure S8). Equilibria between pairs of $\mathrm{Ci}(\mathrm{i}=1,2,3,4)$ corresponded to a

301 keto-enol mediated isomerization (Figure S12), as previously shown for $1 H$-indene-1-carboxylic

302 acid and $1 H$-indene-3-carboxylic acid in water[48]. TP $\mathrm{C} 1, \mathrm{C} 2, \mathrm{C} 3$ and $\mathrm{C} 4$ were assigned to

303 tetrachloroindene-4-carboxylic acid, tetrachloroindene-7-carboxylic acid, trichloroindene-4-

304 carboxylic acid and trichloroindene-7-carboxylic acid, respectively. Esterification of these pairs

305 of TP using methanol led to the formation of $\mathrm{Di}(\mathrm{i}=1,2,3,4)$, while ethanol gave rise to $\mathrm{Ej}$

$306(\mathrm{j}=1,2,3,4)$ (Figure S6). This confirmed the presence of methyl- and ethyl-indene-carboxylate

307 structures and ester functions on the indene ring for $\mathrm{Di}(\mathrm{i}=1,2,3,4)$ and $\mathrm{Ej}(\mathrm{j}=1,2,3,4) \mathrm{TP}$, i.e.

308 either on carbon 4 or 7. 


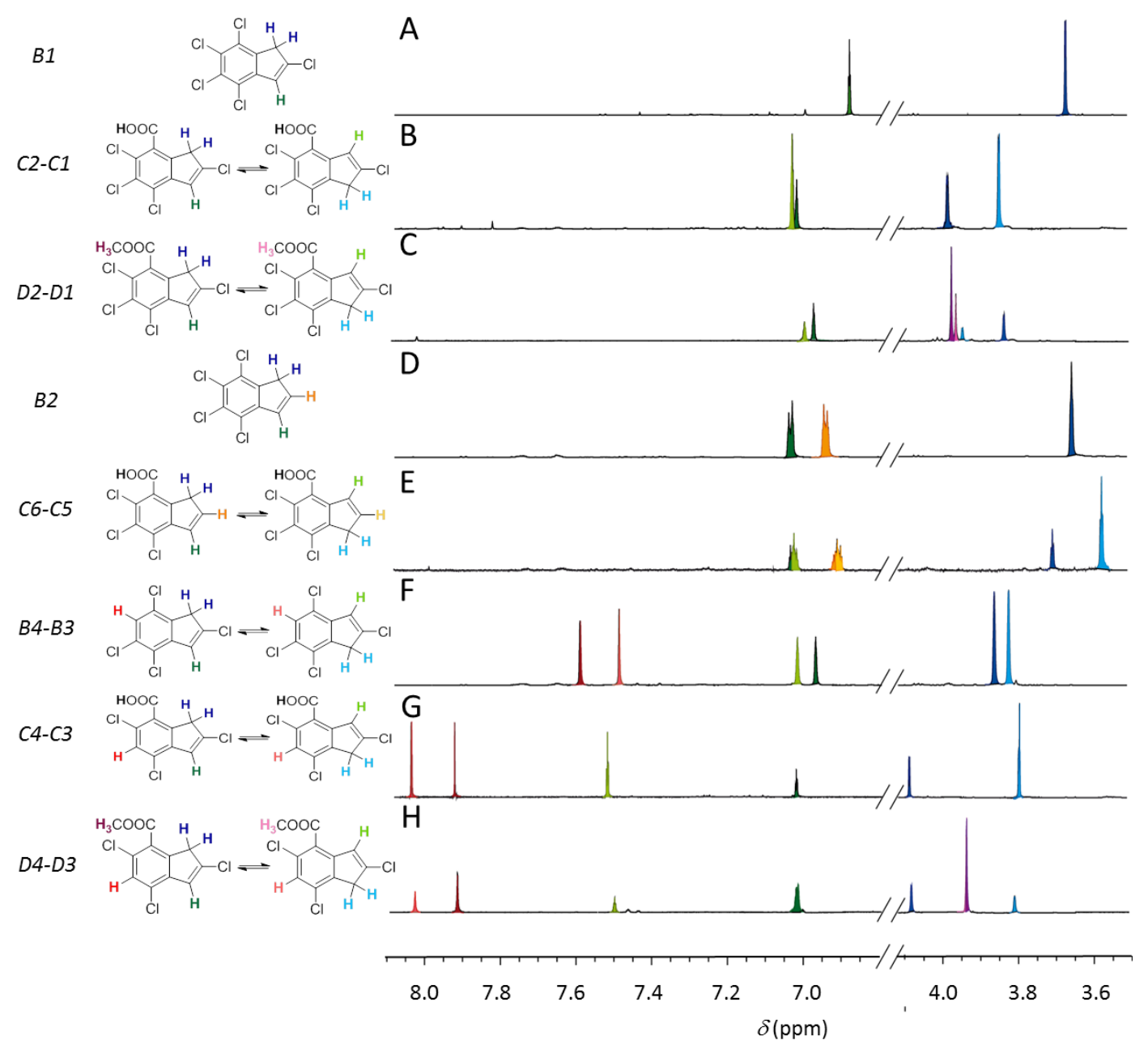

310 Figure 3. Relevant ${ }^{1} \mathrm{H}$ NMR spectra regions of selected indene-based TP (600 MHz). Data were

311 recorded in $\left(\mathrm{CD}_{3}\right)_{2} \mathrm{CO}$ excepted for $\mathrm{B} 1$, recorded in $\mathrm{CDCl}_{3}$. The spectral regions $\delta 3.5-4.1 \mathrm{ppm}$

312 and $\delta 6.8-8.1 \mathrm{ppm}$ are shown for B1 (A), C1-C2 (B), D1-D2 (C), B2 (D), C5-C6 (E), B3-B4 (F),

313 C3-C4 (G), D3-D4 (H).

315 Pentachloroindene B1 was then used as a reference compound for the 4 identified indene-based

316 TP families (Figure 3) in subsequent NMR analyses since it was the first TP to have been

317 elucidated by NMR. ${ }^{1} \mathrm{H}$ NMR and COSY spectra indicated an allylic domain at $\delta 3.7 \mathrm{ppm}(\mathrm{d}, \mathrm{J}=$ $3181.4 \mathrm{~Hz}, 2 \mathrm{H})$ coupled to an aromatic proton at $\delta 6.87 \mathrm{ppm}(\mathrm{t}, \mathrm{J}=1.4 \mathrm{~Hz}, 1 \mathrm{H})$. For indene 
319 systems, a value of 1.4-Hertz indicates a ${ }^{3} \mathrm{~J}$ - or ${ }^{4} \mathrm{~J}$-type coupling constant (Figure S26) leaving 320 possibilities for a proton at carbon position 2, 3 or 7 for the structure of B1. Further NMR 321 analyses of B1 (Figures S27-S33) did not allow to elucidate the proton position, so ${ }^{13}$ C-enriched 322 B1 was synthesized from commercially available ${ }^{13} \mathrm{C}_{8}$-CLD to perform a ${ }^{13} \mathrm{C}-{ }^{13} \mathrm{C} \mathrm{COSY}$ 323 experiment (Figure S35). Each carbon atom could thereby be linked to its direct carbon 324 neighbors, and B1 could then be eventually unequivocally assigned to 2,4,5,6,7-pentachloro- $1 H$ 325 indene by way of a HSQC experiment (Figure S32).

326 TP $\mathrm{C} 1-\mathrm{C} 2$ and D1-D2 represented mixtures of isomers according to ${ }^{1} \mathrm{H}$ NMR and COSY 327 experiments (Figure 3 and Figures S48, S57). Comparison of ${ }^{1} \mathrm{H}$ and ${ }^{13} \mathrm{C}$ NMR spectra 328 highlighted the similarity between TP B1, C1-C2, and D1-D2 (Figure 3 and Figures S30, S47, 329 S58), and all protons of $\mathrm{C} 1-\mathrm{C} 2$ and D1-D2 were unambiguously positioned on the five330 membered ring moiety of the indene structure. Interestingly, the HMBC experiment of C1-C2 331 showed only one cross correlation peak between the most deshielded allylic protons and a 332 carboxylate carbon atom from one of the two carboxyl groups (Figure S50). This set of ${ }^{1} \mathrm{H}$ and $333{ }^{13} \mathrm{C}$ signals was thus assigned to 2,5,6,7-tetrachloro- $1 H$-indene-7-carboxylic acid, i.e. $\mathrm{C} 2$, and the 334 other set to 2,5,6,7-tetrachloro-1H-indene-4-carboxylic acid, i.e. C1 (Figure 3). The same 335 deshielding effect was responsible for chemical shift differences for both ${ }^{1} \mathrm{H}$ and ${ }^{13} \mathrm{C}$ spectra 336 between allylic signals of D1-D2, although no difference in HMBC spectrum was observed for 337 D1-D2. This allowed to unequivocally assign the sets of ${ }^{1} \mathrm{H}$ and ${ }^{13} \mathrm{C}$ signals in these TP (Figure 3 338 and Figures. S57-S61).

339 TP B2 and C5-C6 showed the same ${ }^{1} \mathrm{H}$ NMR pattern (i.e. one triplet in the allylic domain, and 340 two doublets of triplets in the aromatic domain) that allowed them to be distinguished from B1, 341 C1-C2 and D1-D2 (Figure 3). All corresponding NMR signals can be affiliated to the 
342 cyclopentadiene part of the indene structure (Figure S26). Structures of B2, C5 and C6 TP were

343 thus identified as 4,5,6,7-tetrachloro- $1 H$-indene, 5,6,7-trichloro- $1 H$-indene-4-carboxylic acid and

344 4,5,6-trichloro-1H-indene-7-carboxylic acid, respectively.

345 Even if tetrachloroindene B3 appeared as a single compound in GC-MS analysis, its ${ }^{1} \mathrm{H}$ NMR

346 spectrum showed two similar sets of signals indicating two regioisomers, arbitrarily termed B3

347 and B4. ${ }^{1}$ H NMR spectra of C3-C4 and D3-D4 strongly resembled that of B3-B4 (Figure 3). By

348 analogy with 2,4,5,6,7-pentachloroindene B1, the methylene groups and the less deshielded

349 aromatic protons of B3-B4, C3-C4 and D3-D4 were positioned on carbons 1 and 3 of the

350 corresponding indene isomers. An additional coupling of $0.6-0.7 \mathrm{~Hz}$ was observed for B3, C3

351 and D3 only, i.e. between methylene protons on carbon position 1 and the most deshielded

352 aromatic proton. In non-substituted indene, such a weak value is observed for methylene protons

353 coupled with aromatic protons placed on carbons 6 and 7 (Figure S26). Therefore, the last

354 aromatic proton of B3, C3 and D3 was positioned on either carbon 6 or 7. Worthy of note,

355 indene isomerization formally transferred substituents from carbon position 4 to position 7 , and

356 from position 5 to position 6 . The complexity of the ${ }^{13} \mathrm{C}$ spectra did not permit complete

357 elucidation. However HMBC and HSQC experiments indicated that both B3 and B4 featured a

358 chlorine substituent at carbon position 4. Hence, B3 possessed a chlorine atom on carbon

359 position 7, leaving only one plausible structure for B4, i.e. 2,4,5,7-tetrachloroindene. In the case

360 of C3 and D3 (and as also observed for C4 and D4), a strong cross correlation peak in HMBC

361 was systematically detected between the unassigned proton and the carbon from the carboxylic

362 and ester functions. This excluded a ${ }^{5} \mathrm{~J}(\mathrm{H}-\mathrm{C})$ coupling and thus discarded carbon position 7 for

363 the remaining aromatic proton. Finally, C3-C4 and D3-D4 were assigned to 2,5,7-trichloro-1H- 
364 indene-4-carboxylic acid, 2,4,6-trichloro- $1 \mathrm{H}$-indene-7-carboxylic acid, methyl 2,5,7-trichloro$3651 H$-indene-4-carboxylate, methyl 2,4,6-trichloro- $1 H$-indene-7-carboxylate, respectively.

366 As previously shown, Ei $(\mathrm{i}=1,2,3,4)$ TP were ethylated forms of $\mathrm{Cj}(\mathrm{j}=1,2,3,4)$ carboxylates

367 (Figure S6). Consequently, E1-E2 and E3-E4 correspond to ethyl 2,5,6,7-tetrachloro- $1 H$-indene368 4-carboxylate, ethyl 2,5,6,7-tetrachloro- $1 \mathrm{H}$-indene-7-carboxylate, ethyl 2,5,7-trichloro- $\mathrm{H}$ 369 indene-4-carboxylate, ethyl 2,4,6-trichloro- $1 H$-indene-7-carboxylate, respectively.

370 NMR analyses combined with chemical derivatization work further allowed to identify and

371 structurally elucidate 19 TP for the first time (Figure S15). This significantly expands the list of 372 fully characterized chlordecone TP, hitherto only comprised of chlordecol, 8373 monohydrochlordecone and 2,8-dihydrochlordecone[41] and corrects previous findings[39, 42, 374 43].

\section{Natural chlordecone degradation on the Martinique Island}

377 In order to validate laboratory results and the discovery of novel chlordecone TP, several 378 representative environmental compartments contaminated with chlordecone were sampled on

379 Martinique Island, including Galion River basin (water, bed sediments and mangrove)[29, 49], 380 andosol, nitisol and ferralsol soils[47, 50], as well as ashes and pumice stones (Table S4). 381 Samples were analyzed using a different extraction protocol than the recommended ISO 17025 382 standard[31, 50,51] in order to preserve their initial chemical composition. Specifically, the 383 initial drying step was omitted for soil analysis to limit volatilization of B, D and E TP. All 384 extracted samples were concentrated and analyzed using GC-MS and LC-HRMS in full-scan 385 mode. Even if full-scan mode reduces intrinsic analytical sensitivity, it enhances the robustness 
386 of TP assignment using isotopic patterns, and also allows detection of other chlorinated 387 analogues. Concentrations of the most abundant TP (A1, chlordecol, B1, C1-C2 and C3-C4) 388 were estimated using external calibration with purified TP standards (Figure S11). Significant 389 variability of extraction efficiency in soils was observed, as a function of both TP structures and 390 matrix nature, as shown for chlordecone and metabolite B1 in andosol and nitisol soils (Figure 391 S10), so non-corrected concentration ranges were provided here. Chlordecone concentration in 392 Galion River was in the range found in previous studies (0.1-2 $\mu \mathrm{g} / \mathrm{L}$ in Galion River[29]). 393 Worthy of note, the concentration of B1 was in the same order of magnitude as chlordecone 394 itself $(0.1-2 \mu \mathrm{g} / \mathrm{L})$ in both Galion River and nearby mangrove (Figure 4 and Table S7). 395 Moreover, B1 could be detected in bed sediments where chlordecone was absent. In soils, 396 chlordecone concentrations were roughly 10-fold lower than previously reported typical values 397 of dried samples (0.01-1 mg/kg compared to $0.8-5 \mathrm{mg} / \mathrm{kg}$ (dry weight) in Martinique[47, 50]). 398 Chlordecone TP were amply found in solid matrices, with B1 and chlordecol being detected in 399 all soil samples excepted in chlordecone-free nitisol 926. TP B1 fluctuated in the range between $400 \quad 0.05$ to $5 \mathrm{mg} / \mathrm{kg}$. In contrast, chlordecol was systematically around $0.05 \mathrm{mg} / \mathrm{kg}$, in agreement 401 with previous studies[40]. TP A1 was only observed at significant levels in the two andosol soils $402(0.05-1 \mathrm{mg} / \mathrm{kg}) . \mathrm{C} 3-\mathrm{C} 4 \mathrm{TP}$, less chlorinated than C1-C2 TP, appeared more frequently and at a 403 higher level, especially in one nitisol soil (above $1 \mathrm{mg} / \mathrm{kg}$ ). The low concentration of 8 404 monohydrochlordecone $(<0.01 \mathrm{mg} / \mathrm{kg})$ agreed with previous studies[33]. While methyl 405 polychloroindenecarboxylates were absent of all samples, many other TP were detected at low 406 level, including di-, tri-hydrochlordecones, tetrachloroindenes (B2, B3-B4), ethyl 407 polychloroindenecarboxylates (E1-E2)(Figure 4 and Table S7). The untargeted analytical 408 approach also led to the discovery of a monohydrochlordecol derivative and two dichloroindene 


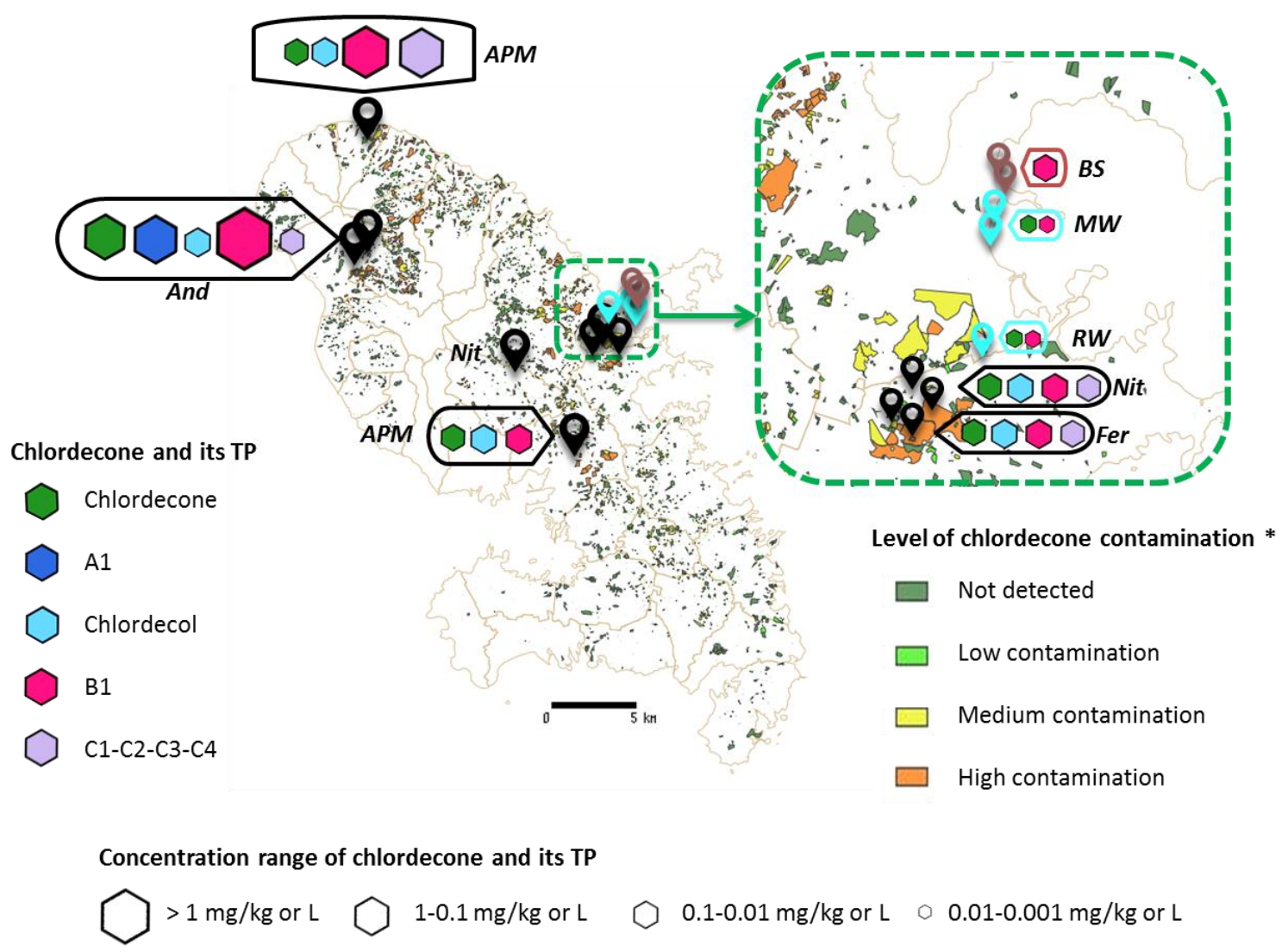

412 Figure 4. Distribution of samplings in Martinique and estimation of chlordecone and TP 413 concentrations. Martinique that was taken 414 http://carto.geomartinique.fr/1/layers/pref_chlordecone_analyse_sol_s_972.map, represents 415 chlordecone contamination according to 2018 sampling campaign. *indicates chlordecone 416 contamination level and were established by the previous quoted website. Samples were 417 classified into type: andosol (And), nitisol (Nit), ferralsol (Fer), ashes and pumice stones (APM), 418 bed sediments (BS), mangrove water (MW), river water (RW) and samplings were done in 419 duplicate. If duplicates were closed, they showed the same chlordecone TP distribution. 420 Samplings were done according to location icons (black ones represent soil samplings, brown: 421 bed sediment and blue: water). 
423 The only previously reported chlordecone derivatives were chlordecol and 8424 monohydrochlordecone, present in FWI soils at much lower levels than chlordecone (0.03-0.5 $425 \mathrm{mg} / \mathrm{kg}$, and $0.05-0.2 \mathrm{mg} / \mathrm{kg}$ respectively)[33, 40]. Chlordecol and 8-monohydrochlordecone were 426 actually known contaminants from commercial chlordecone, and were as such the only 427 chlordecone derivatives included in targeted analyses until today. Even if our dual GC-MS- and 428 LC-HRMS-based approach was intrinsically less sensitive, it allowed us to uncover in 429 environmental samples the presence of numerous hidden chlordecone TP.

430 Altogether, this study shows that four of the five identified TP families occur in natural soil and 431 water samples from Martinique, and include a total of 17 TP initially absent in chlordecone 432 commercial formulations. Pentachloroindene B1 was the most prominent TP, with levels similar 433 to those of chlordecone (Figure 4). Bacteria known to transform chlordecone into A, B and C 434 families[36] were searched in the studied soil samples using Illumina sequencing of the 16S 435 rRNA gene (V4-V5 amplicons) following DNA extraction. Only a very low frequency (1.4 to $4362.10^{-4}$ ) of Citrobacter affiliated sequences was found, and this in only three of the investigated 437 samples $(918,919 \& 920)$. Thus, based on current knowledge of bacterial diversity associated 438 with chlordecone degradation, the overall bacterial contribution to chlordecone degradation in 439 Martinique native soils may not be identified yet.

440 Finally, exploratory soil/liquid microcosms were set up under anoxic conditions with three 441 representative FWI soils contaminated with chlordecone, (i.e. one andosol (914), one nitisol 442 (918) and one ferralsol (919)). These experiments were further used to inoculate liquid culture 443 supplemented with $40 \mathrm{mg} / \mathrm{L}$ of chlordecone. Degradation in all experiments and the concomitant 444 formation of TP (Figure S9) confirmed the intrinsic widespread natural chlordecone degradation 
445 in natural FWI soils, as well as the production of many novel chlordecone TP that had hitherto 446 remained undetected.

447 Taken together, our results raise the issue of the real extent of chlordecone pollution in the FWI 448 that goes beyond the parent molecule and includes a significant number of TP. Their structural 449 diversity illustrates the hitherto unsuspected extant complexity of processes and pathways. 450 Further mechanistic investigations will benefit from the large panel of purified and elucidated 451 TP. As phylogenetic analyses suggest strong differences between the FWI bacterial community 452 and the previous reported bacteria associated with chlordecone degradation, it cannot be 453 excluded that other chlordecone TP yet undetected may also be formed under field conditions. 454 The paradigm of absolute chlordecone persistence taken for granted for decades[31] now clearly 455 appears obsolete and calls for setting new monitoring and risk priorities. Synthetic access to this 456 new panel of chlordecone TP opens the doors to accurate environmental quantification protocols, 457 toxicological studies and biodegradation assays. Last but not least, the original untargeted dual 458 GC/MS- and LC/HRMS-based approach we used may also be applied to other POP such as 459 mirex which shares the same perchlorinated bishomocubane structure to assess their global 460 environmental biodegradability. ASSOCIATED CONTENT

\section{Supporting Information.}

464 The Supporting Information is available free of charge on the ACS Publications website at DOI: 
467 Corresponding Author

468 * E-mail: plsaaidi@genoscope.cns.fr or denis@genoscope.cns.fr.

469 Author Contributions

$470 \quad{ }^{1}$ M.C. and O.D.N. contributed equally

$471 \quad{ }^{2}$ S.C., A.B. and D.M. also contributed equally

$472 \quad$ Notes

473 The authors declare no competing financial interest.

474

\section{ACKNOWLEDGMENT}

476 Support was provided by the INRA AIP Demichlord part of "Plan Chlordecone", Commissariat à

477 l'Energie Atomique et aux Energies Alternatives (CEA), the Centre National de Recherche

478 Scientifique (CNRS) and the University Evry Val d'Essonne (UEVE). MC work was funded by

479 CEA and ODN work was supported by the "IDI 2017" project funded by the IDEX Paris-Saclay,

480 ANR-11-IDEX-0003-02. We also thank Magalie Lesueur-Jannoyer and Cécile Fischer for 481 helpful discussions; Olek Maciejak for assistance in NMR data collection; and Grégoire David, 482 Eddy Elisée, Stéphanie Fouteau, Caroline Menguy, Charles Mottes, Tiffany Prevost and Luc 483 Rangon for technical assistance. Institut de Chimie des Substances Naturelles, UEVE are 484 acknowledged for NMR and MS facilities, and The Region Ile de France and CNRS for their 485 contributions to NMR equipment. 
1. Matolcsy, C.; Nadasy, M.; Andriska, V., Pesticide chemistry. Studies in environnemental sciences 1988, 32, 1-809.

490 2. NRC, Kepone/Mirex/Hexachlorocyclopentadiene An environment assessment. 491 Environmental Studies Board 1978.

492 3. Servien, R.; Mamy, L.; Li, Z.; Rossard, V.; Latrille, E.; Bessac, F.; Patureau, D.; Benoit, 493 P., TyPol - A new methodology for organic compounds clustering based on their molecular 494 characteristics and environmental behavior. Chemosphere 2014, 111, 613-622.

495 4. Carlson, D. A.; Konyha, K. D.; Wheeler, W. B.; Marshall, G. P.; Zaylskie, R. G., Mirex 496 in the environment: its degradation to kepone and related compounds. Science 1976, 194, (4268), $497 \quad 939-41$.

498 5. Figge, K.; Rehm, H., On the behaviour of the insectide "kelevan" and its metabolites in 499 the ecological system "potato field". Journal of plant disease and protection 1977, 84, 385-409.

500 6. Le Déaut, J. Y.; Procaccia, C., Les impacts de l'utilisation de la chlordécone et des 501 pesticides aux Antilles: bilan et perspectives d'évolution. OPECST 2009, 487.

502 7. Yang, R.; Wei, H.; Guo, J.; McLeod, C.; Li, A.; Sturchio, N. C., Historically and 503 currently used Dechloranes in the sediments of the Great Lakes. Environmental science \& 504 technology 2011, 45, (12), 5156-63.

505 8. Bell, M. A.; Ewing, R. A.; Lutz Batelle, G. A., Reviews of the environmental effects of pollutants : I Mirex and Kepone. United States Environmental Protection Agency 1978, 1-252. 9. Wang, B.; Iino, F.; Yu, G.; Huang, J.; Wei, Y.; Yamazaki, N.; Chen, J.; Chen, X.; Jiang, W.; Morita, M., HRGC/HRMS analysis of mirex in soil of Liyang and preliminary assessment of mirex pollution in China. Chemosphere 2010, 79, (3), 299-304.

10. Roche, H.; Salvat, B.; Ramade, F., Study on the contamination of marine organisms by pesticides from French Polynesia coral reef food web. Rev Ecol 2011, 66, 3-10.

11. Huggett, R. J.; Bender, M. E., Kepone in the James River. Environmental science \& technology 1980, 14, (8), 918-923.

12. Vilardebo, A.; Beugnon, M.; Melin, P.; Lecoq, J.; Aubert, B., Chlordécone et autres insecticides dans la lutte contre le charançon du bananier Cosmopolites sordidus GERM. Fruits 1974, 29, (4), 267-278.

13. Fournier, A.; Feidt, C.; Lastel, M. L.; Archimede, H.; Thome, J. P.; Mahieu, M.; Rychen, G., Toxicokinetics of chlordecone in goats: Implications for risk management in French West Indies. Chemosphere 2017, 171, 564-570.

14. Epstein, S. S., Kepone--hazard evaluation. The Science of the total environment 1978, 9 , (1), 1-62.

15. Multigner, L.; Ndong, J. R.; Giusti, A.; Romana, M.; Delacroix-Maillard, H.; Cordier, S.; Jegou, B.; Thome, J. P.; Blanchet, P., Chlordecone exposure and risk of prostate cancer. Journal of clinical oncology : official journal of the American Society of Clinical Oncology 2010, 28, (21), 3457-62.

16. Dallaire, R.; Muckle, G.; Rouget, F.; Kadhel, P.; Bataille, H.; Guldner, L.; Seurin, S.; Chajes, V.; Monfort, C.; Boucher, O.; Thome, J. P.; Jacobson, S. W.; Multigner, L.; Cordier, S., 
Cognitive, visual, and motor development of 7-month-old Guadeloupean infants exposed to chlordecone. Environmental research 2012, 118, 79-85.

$530 \quad$ 17. Seurin, S.; Rouget, F.; Reninger, J. C.; Gillot, N.; Loynet, C.; Cordier, S.; Multigner, L.; Leblanc, J. C.; Volatier, J. L.; Heraud, F., Dietary exposure of 18-month-old Guadeloupian toddlers to chlordecone. Regulatory toxicology and pharmacology : RTP 2012, 63, (3), 471-9. Dallaire, R.; Monfort, C.; Thome, J. P.; Multigner, L.; Cordier, S., Exposure to an organochlorine pesticide (chlordecone) and development of 18-month-old infants. Neurotoxicology 2013, 35, 162-8.

537 19. Kadhel, P.; Monfort, C.; Costet, N.; Rouget, F.; Thome, J. P.; Multigner, L.; Cordier, S., Chlordecone exposure, length of gestation, and risk of preterm birth. American journal of epidemiology 2014, 179, (5), 536-44.

$540 \quad 20 . \quad$ Saunders, L.; Kadhel, P.; Costet, N.; Rouget, F.; Monfort, C.; Thome, J. P.; Guldner, L.; Cordier, S.; Multigner, L., Hypertensive disorders of pregnancy and gestational diabetes mellitus among French Caribbean women chronically exposed to chlordecone. Environment international 2014, 68, 171-6.

21. Cordier, S.; Bouquet, E.; Warembourg, C.; Massart, C.; Rouget, F.; Kadhel, P.; Bataille, H.; Monfort, C.; Boucher, O.; Muckle, G.; Multigner, L., Perinatal exposure to chlordecone, thyroid hormone status and neurodevelopment in infants: the Timoun cohort study in Guadeloupe (French West Indies). Environmental research 2015, 138, 271-8. Cordier, S., Prenatal exposure to chlordecone, gestational weight gain, and birth weight in a Guadeloupean birth cohort. Environmental research 2016, 151, 436-444.

23. Multigner, L.; Kadhel, P.; Rouget, F.; Blanchet, P.; Cordier, S., Chlordecone exposure and adverse effects in French West Indies populations. Environmental science and pollution research international 2016, 23, (1), 3-8.

554 24. Yang, Y. F.; Chen, P. J.; Liao, V. H., Nanoscale zerovalent iron (nZVI) at environmentally relevant concentrations induced multigenerational reproductive toxicity in Caenorhabditis elegans. Chemosphere 2016, 150, 615-23. P.; Brureau, L., Prostate cancer clinical presentation, incidence, mortality and survival in Guadeloupe over the period 2008-2013 from a population-based cancer registry. Cancer causes \& control : CCC 2017, 28, (11), 1265-1273.

561 26. Gely-Pernot, A.; Hao, C.; Legoff, L.; Multigner, L.; D'Cruz, S. C.; Kervarrec, C.; Jegou, 562 B.; Tevosian, S.; Smagulova, F., Gestational exposure to chlordecone promotes transgenerational 563 changes in the murine reproductive system of males. Scientific reports 2018, 8, (1), 10274.

564 27. Clostre, F.; Cattan, P.; Gaude, J. M.; Carles, C.; Letourmy, P.; Lesueur-Jannoyer, M., 565 Comparative fate of an organochlorine, chlordecone, and a related compound, chlordecone-5bhydro, in soils and plants. The Science of the total environment 2015, 532, 292-300.

570 29. Della Rossa, P.; Jannoyer, M.; Mottes, C.; Plet, J.; Bazizi, A.; Arnaud, L.; Jestin, A.; 571 Woignier, T.; Gaude, J. M.; Cattan, P., Linking current river pollution to historical pesticide use: 572 Insights for territorial management? The Science of the total environment 2017, 574, 1232-1242. 
30. Unger, M. A.; Vadas, G. G., Kepone in the James River Estuary: Past, Current and Future Trends. . Virginia Institute of Marine Science, College of William and Mary. 2017, 1-15. 31. Cabidoche, Y. M.; Achard, R.; Cattan, P.; Clermont-Dauphin, C.; Massat, F.; Sansoulet, J., Long-term pollution by chlordecone of tropical volcanic soils in the French West Indies: a simple leaching model accounts for current residue. Environ Pollut 2009, 157, (5), 1697-705.

32. Fernández-Bayo, J. D.; Saison, C.; Voltz, M.; Disko, U.; Hofmann, D.; Berns, A. E., Chlordecone fate and mineralisation in a tropical soil (andosol) microcosm under aerobic conditions. The Science of the total environment 2013, 463-464, 395-403.

33. Devault, D. A.; Laplanche, C.; Pascaline, H.; Bristeau, S.; Mouvet, C.; Macarie, H., Natural transformation of chlordecone into 5b-hydrochlordecone in French West Indies soils: statistical evidence for investigating long-term persistence of organic pollutants. Environmental science and pollution research international 2016, 23, (1), 81-97.

34. Orndorff, S. A.; Colwell, R. R., Distribution and characterization of kepone-resistant bacteria in the aquatic environment. Applied and environmental microbiology 1980, 39, (3), 61122.

35. George, S. E.; Claxton, L. D., Biotransformation of chlordecone by Pseudomonas species. Xenobiotica; the fate of foreign compounds in biological systems 1988, 18, (4), 407-16.

36. Chaussonnerie, S.; Saaidi, P. L.; Ugarte, E.; Barbance, A.; Fossey, A.; Barbe, V.; Gyapay, G.; Bruls, T.; Chevallier, M.; Couturat, L.; Fouteau, S.; Muselet, D.; Pateau, E.; Cohen, G. N.; Fonknechten, N.; Weissenbach, J.; Le Paslier, D., Microbial Degradation of a Recalcitrant Pesticide: Chlordecone. Frontiers in microbiology 2016, 7, (2025), 2025.

37. Chevallier, M. L.; Cooper, M.; Kummel, S.; Barbance, A.; Le Paslier, D.; Richnow, H. H.; Saaidi, P. L.; Adrian, L., Distinct Carbon Isotope Fractionation Signatures during Biotic and Abiotic Reductive Transformation of Chlordecone. Environmental science \& technology 2018, $52,(6), 3615-3624$.

38. Jablonski, P. E.; Pheasant, D. J.; Ferry, J. G., Conversion of Kepone by Methanosarcina thermophila. FEMS microbiology letters 1996, 139, (2-3), 169-173.

39. Schrauzer, G. N.; Katz, R. N., Reductive dechlorination and degradation of mirex and kepone with Vitamin B12. Bioinorganic chemistry 1978, 9, (2), 123-43.

40. Almaric, L.; Bristeau, S. Essai d'intercomparaison de l'analyse de la chlordécone et de ses métabolites dans les sols; BRGM/RP-63113-FR; BRGM: 2014; p 87.

41. Wilson, N. K.; Zehr, R. D., Structures of some Kepone photoproducts and related chlorinated pentacyclodecanes by carbon-13 and proton nuclear magnetic resonance. The Journal of organic chemistry 1979, 44, (8), 1278-1282.

42. Belghit, H.; Colas, C.; Bristeau, S.; Mouvet, C.; Maunit, B., Liquid chromatographyhigh-resolution mass spectrometry for identifying aqueous chlordecone hydrate dechlorinated transformation products formed by reaction with zero-valent iron. International Journal of Environmental Analytical Chemistry 2015, 95, (2), 93-105.

43. Ranguin, R.; Durimel, A.; Karioua, R.; Gaspard, S., Study of chlordecone desorption from activated carbons and subsequent dechlorination by reduced cobalamin. Environmental science and pollution research international 2017, 24, (33), 25488-25499.

44. Lewis, T. A.; Morra, M. J.; Brown, P. D., Comparative product analysis of carbon tetrachloride dehalogenation catalyzed by cobalt corrins in the presence of thiol or titanium (III) reducing agents. Environmental science \& technology 1996, 30, (1), 292-300.

45. Rodríguez-Garrido, B.; Camps Arbestain, M.; Monterroso, M. C.; Macías, F., Reductive Dechlorination of $\alpha-, \beta-, \delta$-, and $\gamma$-Hexachlorocyclohexane Isomers by Hydroxocobalamin in the 
619 Presence of Either Dithiothreitol or Titanium(III) Citrate as Reducing Agents. Environmental 620 science \& technology 2004, 38, (19), 5046-5052.

621 46. Holmstead, R. L., Studies of the degradation of Mirex with an iron(II) porphyrin model 622 system. Journal of agricultural and food chemistry 1976, 24, (3), 620-4.

623 47. Mouvet, C.; Dictor, M. C.; Bristeau, S.; Breeze, D.; Mercier, A., Remediation by 624 chemical reduction in laboratory mesocosms of three chlordecone-contaminated tropical soils. 625 Environmental science and pollution research international 2017, 24, (33), 25500-25512.

626 48. Andraos, J.; Kresge, A. J.; Popik, V. V., Kinetics and Mechanism of the Isomerization of 627 1H-Indene-1-carboxylic Acid to 1H-Indene-3-carboxylic Acid in Aqueous Solution and 628 Determination of Their Keto-Enol Equilibrium Constants and Acid Dissociation Constants of the 629 Keto and Enol Forms. Implication for the Photolysis of Diazonaphthoquinones. Journal of the 630 American Chemical Society 1994, 116, (3), 961-967.

631 49. Robert, S. Historique de la contamination des sédiments littoraux des Antilles françaises 632 par la chlordécone (ChloSed). Rapport final de convention MAAP-Ifremer.; Ifremer: 633 L'Houmeau, 2012; p 92.

634 50. Brunet, D.; Woignier, T.; Lesueur-Jannoyer, M.; Achard, R.; Rangon, L.; Barthes, B. G., 635 Determination of soil content in chlordecone (organochlorine pesticide) using near infrared reflectance spectroscopy (NIRS). Environ Pollut 2009, 157, (11), 3120-5.

638 remediated French West Indies soils with high organic matter content. Analytical and 639 bioanalytical chemistry 2014, 406, (4), 1073-80. 